\title{
Meningkatkan Penyesuaian Diri Siswa Terhadap Program Peminatan MIPA Melalui Bimbingan Klasikal Teknik Sosiodrama
}

\author{
Ayu Lailatuz Zakkiyyah ${ }^{1}$, Muslikah ${ }^{2}$ \\ Jurusan Bimbingan dan Konseling, Fakultas Ilmu Pendidikan, \\ Universitas Negeri Semarang, Indonesia ${ }^{1,2}$ \\ Email: ayulailatuz@gmail.com ${ }^{1}$, muslikah@mail.unnes.ac.id ${ }^{2}$
}

\begin{abstract}
:
The purpose of this research is to know empirically the effectiveness of classical sociodrama techniques to improve the adjustment of students ten class MIPA specialization program. The method of this research is experimental research, and use one group pretest-posttest design. Subjects were taken using simple random sampling technique with threety six students. The instrument that used in this research is the scale of adjustment to the MIPA specialization program. Data analysis using analysis describtive. The results showed that this study was effective. From the results of this research, It means that the classical guidance of sociodrama techniques is effective to improve the adjustment of students ten class MIPA specialization program.
\end{abstract}

Keyword: Classical Guidance, Adjustment, MIPA Specialization Program, Sosiodrama Technique.

Received August 09, 2018; Revised September 13, 2018; Accepted October 01, 2018

How to Cite: Zakkiyyah A. L., \& Muslikah. (2018). Meningkatkan Penyesuaian Diri Siswa Terhadap Program Peminatan MIPA Melalui Bimbingan Klasikal Teknik Sosiodrama. JKI (Jurnal Konseling Indonesia), 4(1), 36-41

\section{PENDAHULUAN}

Masa remaja merupakan transisi atau masa peralihan antara masa kanak-kanak dan masa dewasa. Pada masa ini berbagai perubahan terjadi, oleh karena itu remaja dituntut untuk mampu menyesuaikan diri, baik dalam lingkungan sekolah, keluarga, maupun masyarakat. Di lingkungan sekolah siswa dituntut mampu menyesuaikan diri dengan baik agar tidak menimbulkan kecemasan yang dapat mengganggu perkembangan siswa (Husna \& Sutoyo, 2016). Penyesuaian diri menjadi faktor penting dalam kehidupan belajar siswa agar dapat meraih prestasi yang optimal dalam bidang akademik maupun non akademik di sekolahnya (Fazar, 2017).

Pada jenjang Sekolah Menengah Atas (SMA) siswa akan dihadapkan pada pemilihan program peminatan. (Permendikbud, 2014) menyatakan bahwa peminatan pada SMA/MA memiliki tujuan untuk memberikan kesempatan kepada peserta didik mengembangkan kompetensi sikap, kompetensi pengetahuan, dan kompetensi keterampilan peserta didik sesuai dengan minat, bakat dan/atau kemampuan akademik dalam sekelompok mata pelajaran keilmuan. Dewasa ini pengambilan program peminatan dimulai ketika siswa 
mendaftar atau memasuki semester 1. Dengan demikian, siswa dituntut untuk semakin memiliki penyesuaian diri yang baik terutama penyesuaian diri terhadap mata pelajaran yang terdapat dalam program peminatan yang diambilnya, mengingat adanya beberapa perbedaan mata pelajaran pada jenjang Sekolah Menengah Pertama (SMP) dengan jenjang Sekolah Menengah Atas (SMA).

Berdasarkan hasil wawancara yang telah dilaksanakan dengan guru bimbingan dan konseling diperoleh informasi bahwa sebagian besar siswa kelas $\mathrm{X}$ memiliki penyesuaian diri yang kurang. Terkait dengan penyesuaian diri terhadap program peminatan di SMA Negeri 1 Demak, guru bimbingan dan konseling mengatakan bahwa hampir seluruh siswa sering mengeluhkan mata pelajaran yang diajarkan, terutama siswa pada program peminatan MIPA. Para siswa masih mengalami kesulitan dalam menyesuaikan diri dengan mata pelajaran yang ada. Hal tersebut terjadi karena pelajaran yang diajarkan di Sekolah Menengah Atas (SMA) dianggap jauh lebih sulit dibandingkan mata pelajaran di Sekolah Menengah Pertama (SMP). Selain itu peneliti juga melakukan wawancara dengan beberapa siswa, diperoleh informasi bahwa beberapa siswa mengalami kesulitan dalam beradaptasi dengan beberapa mata pelajaran. Hal tersebut disebabkan karena sulitnya mata pelajaran di program peminatan MIPA. Terkait dengan pergaulan, siswa mengaku bahwa masih banyak siswa yang menggerombol kecil. Siswa juga mengaku bahwa siswa pada program peminatan MIPA cenderung individual dan sulit diajak kerjasama, terutama ketika mengerjakan tugas kelompok. Fenomena tersebut diperkuat dengan hasil wawancara yang dilakukan kembali dengan guru bimbingan dan konseling dan diperoleh informasi bahwa siswa terutama bagi siswa kelas X sangat memerlukan layanan guna meningkatkan penyesuaian dirinya, baik terhadap lingkungan sekolah maupun terhadap program peminatan yang diambilnya, dikarenakan masih adanya siswa yang memilih program peminatan atas dasar dorongan dari orang tua, sehingga tak jarang siswa merasa kesulitan dalam penyesuaian dirinya, terutama terhadap mata pelajaran.

Adapun dampak yang akan muncul apabila siswa tidak dapat menyesuaikan diri dengan program peminatan MIPA maka siswa akan mengalami kesulitan dalam mengikuti proses belajar mengajar di kelas, prestasi belajar terus menurun, bahkan tidak naik kelas. Hal tersebut dikuatkan oleh Marlina et al. (2015) yang menyatakan bahwa dampak siswa yang merasa dalam jurusan yang tidak sesuai dengan minatnya mengakibatkan siswa tidak bisa menerima pelajaran dengan baik, kurang konsentrasi, acuh tak acuh, dan kadang berakhir dengan putus sekolah. Oleh karena itu, diperlukan penanganan segera agar siswa mampu menyesuaikan diri terhadap program peminatan yang diambilnya dan dampak tersebut tidak terjadi.

Salah satu strategi yang dapat digunakan untuk membantu siswa dalam meningkatkan penyesuaian dirinya terhadap program peminatan MIPA adalah bimbingan klasikal (Makrifah, 2014). Bimbingan klasikal dipilih mengingat hampir seluruh siswa mengalami kesulitan dalam menyesuaikan diri dengan program peminatan yang diambilnya. Bimbingan klasikal yaitu layanan bimbingan yang sasarannya pada seluruh siswa dalam kelas atau gabungan beberapa kelas (Supriyo, 2010). Bimbingan klasikal dapat membantu siswa dalam menyesuaikan diri, mengambil keputusan untuk hidupnya sendiri, mampu beradaptasi dalam kelompoknya, mampu meningkatkan harga diri, konsep diri, dan mampu menerima support dan memberikan support pada temannya (Rosidah, 2017).

Dalam pelaksanaannya, bimbingan klasikal dapat diberikan dengan menggunakan teknik yang disesuaikan dengan kondisi dan permasalahan siswa, salah satunya adalah teknik sosiodrama. Menurut Ahmadi dalam Azizah (2013) teknik sosiodrama adalah salah satu cara dalam bimbingan yang memberikan kesempatan pada murid-murid untuk mendramatisasikan sikap, tingkah laku atau penghayatan seseorang seperti yang dilakukan dalam hubungan sosial sehari-hari di masyarakat. Berdasarkan penelitian yang dilakukan oleh (Nursafitri, 2013), terlihat adanya peningkatan kemampuan hubungan interpersonal siswa setelah mendapatkan perlakuan berupa layanan bimbingan kelompok dengan teknik sosiodrama. Dengan adanya peningkatan tersebut, dapat diketahui bahwa teknik sosiodrama efektif digunakan untuk meningkatkan kemampuan hubungan interpersonal siswa. Dengan demikian, teknik sosiodrama juga dirasa cukup efektif digunakan untuk meningkatkan penyesuaian diri siswa kelas $\mathrm{X}$ terhadap program peminatan MIPA.

Penelitian ini bertujuan untuk mengetahui tingkat penyesuaian diri siswa kelas $\mathrm{X}$ terhadap program peminatan MIPA di SMA Negeri 1 Demak sebelum mengikuti bimbingan klasikal teknik sosiodrama, mengetahui tingkat penyesuaian diri siswa kelas $X$ terhadap program peminatan MIPA di SMA Negeri 1 
Demak sesudah mengikuti bimbingan klasikal teknik sosiodrama, serta mengetahui perbedaan tingkat penyesuaian diri siswa kelas $\mathrm{X}$ terhadap program peminatan MIPA sebelum dan sesudah mengikuti bimbingan klasikal teknik sosiodrama.

\section{METODE PENELITIAN}

Metode yang digunakan dalam penelitian ini adalah metode penelitian eksperimen dan menggunakan desain one group pretest-posttest design (Creswell \& Creswell, 2017). Melalui desain ini, peneliti melakukan pengukuran sebanyak dua kali. Pengukuran yang pertama dilakukan untuk mengukur penyesuaian diri siswa kelas X terhadap peminatan MIPA sebelum adanya perlakuan (pretest) dan pengukuran yang kedua dilakukan untuk mengukur penyesuaian diri siswa kelas $\mathrm{X}$ terhadap peminatan MIPA sesudah adanya perlakuan (posttest). Setelah dilakukan pengukuran, peneliti membandingkan hasil pengukuran dari pretest dan posttest. Layanan bimbingan klasikal teknik sosiodrama ini dilakukan sebanyak enam kali pertemuan.

Pada penelitian ini terdapat dua variabel, yaitu variabel bebas $(\mathrm{X})$ dan variabel terikat $(\mathrm{Y})$. Variabel bebas $(\mathrm{X})$ dalam penelitian ini adalah bimbingan klasikal teknik sosiodrama. Sedangkan variabel terikat (Y) dalam penelitian ini adalah penyesuaian diri siswa terhadap program peminatan MIPA. Subjek dari penelitian ini adalah siswa kelas X MIPA 2 yang berjumlah 36 siswa. Pemilihan subjek dilakukan dengan menggunakan teknik simple random sampling.

Metode pengumpulan data yang digunakan dalam penelitian ini adalah skala psikologis. Menurut Sutoyo (2012) skala psikologis digunakan untuk mengungkap konstruk atau konsep skala psikologis yang menggambarkan aspek kepribadian individu seperti: tendensi agresifitas, sikap terhadap sesuatu, self esteem, kecemasan, persepsi, dan motivasi. Dalam kaitannya dengan penelitian ini, skala psikologis digunakan untuk mengukur tingkat penyesuaian diri siswa kelas $\mathrm{X}$ terhadap program peminatan MIPA sebelum maupun sesudah diberi layanan bimbingan klasikal teknik sosiodrama. Analisis data dalam penelitian ini menggunakan analisis deskriptif persentase dan uji t-test.

\section{HASIL}

Berdasarkan hasil perhitungan pretest, diperoleh hasil rata-rata penyesuaian diri siswa kelas $\mathrm{X}$ terhadap program peminatan MIPA sebelum mengikuti bimbingan klasikal teknik sosiodrama sebesar 58\% dan masuk dalam kategori sedang. Selanjutnya berdasarkan hasil perhitungan posttest, diperoleh hasil rata-rata persentase penyesuaian diri siswa kelas X terhadap program peminatan MIPA sebesar 75\% dan masuk dalam kategori tinggi. Dengan demikian, diketahui bahwa terjadi peningkatan penyesuaian diri siswa kelas $\mathrm{X}$ terhadap program peminatan MIPA sebelum dan sesudah mengikuti layanan bimbingan klasikal teknik sosiodrama. Adapun hasil persentase penyesuaian diri siswa kelas X terhadap program peminatan MIPA sebelum dan sesudah mengikuti bimbingan klasikal teknik sosiodrama perindikator dapat dilihat pada tabel 1 berikut ini:

Tabel 1. Hasil Persentase Sebelum dan Sesudah Mengikuti Bimbingan Klasikal Teknik Sosiodrama Perindikator

\begin{tabular}{llllll}
\hline \multirow{2}{*}{ Indikator } & Pre Test & \multicolumn{3}{c}{ Post Test } & Persentase \\
\cline { 2 - 5 } & Persentase & Kriteria & Persentase & Kriteria & \\
\hline Kematangan Pribadi & $57 \%$ & Sedang & $75 \%$ & Tinggi & $18 \%$ \\
Kematangan Sosial & $58 \%$ & Sedang & $75 \%$ & Tinggi & $17 \%$ \\
Kematangan & $57 \%$ & Sedang & $74 \%$ & Tinggi & $17 \%$ \\
Intelektual/Pendidikan & $59 \%$ & Sedang & $77 \%$ & Tinggi & $18 \%$ \\
Tanggung Jawab & $\mathbf{5 8 \%}$ & Sedang & $\mathbf{7 5 \%}$ & Tinggi & $\mathbf{1 7 \%}$ \\
\hline Rata-rata & & &
\end{tabular}

Hipotesis yang diajukan dalam penelitian ini adalah "bimbingan klasikal dengan teknik sosiodrama efektif digunakan untuk meningkatkan penyesuaian diri siswa kelas X terhadap program peminatan MIPA di 
SMA Negeri 1 Demak". Untuk mengetahui keefektifan bimbingan klasikal dengan teknik sosiodrama untuk meningkatkan penyesuaian diri siswa kelas X terhadap program peminatan MIPA di SMA Negeri 1 Demak dapat dilihat dari ada tidaknya peningkatan penyesuaian diri siswa kelas $\mathrm{X}$ terhadap program peminatan MIPA sebelum dan sesudah mengikuti bimbingan klasikal teknik sosiodrama. Pada penelitian ini, untuk mengetahui peningkatan penyesuaian diri siswa kelas $X$ terhadap program peminatan MIPA sebelum dan sesudah mengikuti bimbingan klasikal teknik sosiodrama dilakukan analisis menggunakan rumus t-test. Adapun hasil analisis data menggunakan uji $t$-test dapat dilihat pada tabel 2 berikut ini:

Tabel 2. Hasil Uji T-Test

\begin{tabular}{lllll}
$\begin{array}{l}\text { Penyesuaian Diri terhadap } \\
\text { Program Peminatan MIPA }\end{array}$ & N & Rata-rata & T $_{\text {hitung }}$ & T $_{\text {tabel }}$ \\
\hline Pretest - Posttest & 36 & 48,889 & 21,959 & 2,028
\end{tabular}

Berdasarkan hasil uji t-test pada tabel 3, diketahui bahwa $t_{\text {hitung }}>\mathrm{t}_{\text {tabel }}(21,959>2,028)$, maka $\mathrm{H}_{\mathrm{a}}$ diterima dan $\mathrm{H}_{0}$ ditolak. Dengan demikian, terbukti bahwa bimbingan klasikal dengan teknik sosiodrama efektif digunakan untuk meningkatkan penyesuaian diri siswa kelas X terhadap program peminatan MIPA di SMA Negeri 1 Demak.

\section{PEMBAHASAN}

Penyesuaian diri adalah interaksi yang terjadi secara terus-menerus baik terhadap diri sendiri, orang lain, maupun lingkungan dalam mencapai keseimbangan untuk memenuhi kebutuhan, mendapatkan rasa aman dan nyaman, bergaul, serta mencapai keharmonisan antara diri individu dengan lingkungan di sekitarnya. Lingkungan merupakan faktor penting yang dapat mempengaruhi penyesuaian diri siswa, terutama lingkungan sekolah. Seorang siswa harus memiliki kemampuan penyesuaian diri yang baik terhadap lingkungan sekolah terutama pada program peminatan yang diambilnya, salah satunya adalah program peminatan MIPA. Apabila siswa tidak dapat menyesuaikan diri dengan baik terhadap program peminatan yang diambilnya maka siswa akan mengalami kesulitan selama mengikuti pembelajaran di kelas, sehingga dapat berdampak pada prestasi siswa seperti nilai yang terus menurun dan adanya kemungkinan tidak naik kelas. Hal tersebut didukung oleh Marlina et al. (2015) yang menyatakan bahwa dampak siswa yang merasa dalam jurusan yang tidak sesuai dengan minatnya mengakibatkan siswa tidak bisa menerima pelajaran dengan baik, kurang konsentrasi, acuh tak acuh, dan kadang berakhir dengan putus sekolah.

Selama pengambilan data awal dan pemberian treatment, diketahui bahwa siswa kelas X MIPA memiliki anggapan bahwa mata pelajaran di Sekolah Menengah Atas (SMA) lebih sulit daripada mata pelajaran di Sekolah Menengah Pertama (SMP). Anggapan tersebut membawa dampak pada beberapa siswa kelas X MIPA yang mengakibatkan siswa tidak menyukai beberapa mata pelajaran yang diajarkan. Ketika siswa tidak menyukai mata pelajaran tersebut, siswa cenderung terlambat masuk kelas ketika jam pelajaran telah dimulai. Selain itu, selama pelajaran siswa lebih memilih untuk ngobrol dengan temannya atau bermain HP daripada mendengarkan penjelasan dari guru yang bersangkutan. Apabila dilihat dari tingkah laku tersebut, diketahui bahwa siswa memiliki penyesuaian diri yang rendah. Oleh karena itu, perlu adanya layanan bimbingan dan konseling untuk meningkatkan penyesuaian diri siswa terhadap program peminatan MIPA. Pada penelitian ini, peneliti memberikan layanan bimbingan klasikal teknik sosiodrama untuk meningkatkan penyesuaian diri siswa kelas X terhadap program peminatan MIPA.

Menurut Mukhtar et al. (2016) bimbingan klasikal merupakan layanan yang diberikan oleh seorang pembimbing dalam lingkup kelas yang dilaksanakan secara sistematis dan memungkinkan adanya kontak langsung antara pembimbing dengan yang dibimbing (siswa). Bimbingan klasikal berguna untuk membantu siswa dalam menyesuaikan dirinya, mandiri dalam pengambilan keputusan, mengajarkan keterampilanketerampilan tertentu, membantu dalam mengembangkan potensi yang dimiliki secara optimal, serta mencapai kesuksesan belajar dan karir di masa depan. Layanan bimbingan klasikal pada penelitian ini 
berfokus pada pemberian materi-materi yang berkaitan dengan penyesuaian diri siswa terhadap program peminatan MIPA.

Pemberian layanan bimbingan klasikal pada penelitian ini menggunakan teknik sosiodrama (Sudirman et al., 2015). Teknik sosiodrama adalah salah satu teknik yang dapat digunakan untuk memecahkan masalahmasalah sosial dengan cara bermain peran atau mendramatisasikan masalah-masalah sosial tersebut, sehingga individu lebih mudah untuk memahami perannya dan belajar peranan baru. Melalui teknik sosiodrama ini, siswa kelas $\mathrm{X}$ dapat lebih mudah dalam memahami masalah-masalah sosial terutama terkait dengan penyesuaian diri terhadap program peminatan MIPA. Hal ini didukung oleh Kusumaningrum et al. (2014) yang menyatakan bahwa dalam sosiodrama, seseorang akan memerankan suatu peran tertentu dari situasi masalah sosial sehingga dia mampu merasa secara langsung peran yang dimainkannya.

Berdasarkan hasil analisis deskripsi persentase diketahui bahwa penyesuaian diri siswa kelas $\mathrm{X}$ terhadap program peminatan MIPA sebelum mengikuti bimbingan klasikal teknik sosiodrama masuk dalam kategori sedang. Hal tersebut dikarenakan siswa baru saja memasuki jenjang Sekolah Menengah Atas (SMA) dan masih memerlukan proses untuk beradaptasi dengan lingkungan baru, sehingga pada awal-awal memasuki jenjang baru ini mereka masih menemukan beberapa ketidakcocokan antara dirinya dan lingkungannya. Hal tersebut sejalan dengan pendapat Astutik et al. (2016) bahwa siswa mulai memasuki jenjang sekolah yang baru, mereka mungkin mengalami permasalahan penyesuaian diri dengan guru-guru, teman dan mata pelajaran.

Selanjutnya, sesudah mengikuti bimbingan klasikal teknik sosiodrama penyesuaian diri siswa kelas X terhadap program peminatan MIPA meningkat dan masuk dalam kategori tinggi. Hal ini dikarenakan penggunaan teknik sosiodrama memiliki kelebihan, yaitu siswa dapat mengembangkan keterampilan dan kreativitas serta siswa dapat lebih mudah memahami masalah sosial dan membentuk perilaku baru. Hal tersebut sejalan dengan pernyataan Corsini dalam Winarlin et al. (2016) bahwa melalui keterlibatan siswa secara aktif dalam proses permainan peranan, siswa dapat mengembangkan pengertian-pengertian baru dan mempraktikkan keterampilan-keterampilan baru.

Peningkatan penyesuaian diri terhadap program peminatan MIPA tersebut terjadi pada seluruh siswa, mengingat bahwa selama mengikuti layanan bimbingan klasikal teknik sosiodrama seluruh siswa antusias dalam mendengarkan dan memperhatikan penampilan drama. Selain itu siswa juga aktif berpendapat mengenai materi yang disampaikan. Peningkatan juga terlihat pada masing-masing indikator, yaitu indikator kematangan pribadi, kematangan sosial, kematangan intelektual/pendidikan, dan tanggung jawab. Peningkatan yang paling menonjol terlihat pada indikator kematangan intelektual/pendidikan dimana R-23 dan R-36 memiliki peningkatan yang sangat baik, yaitu dari kategori sedang menjadi kategori sangat tinggi. Dengan adanya peningkatan tersebut, diketahui bahwa bimbingan klasikal dengan teknik sosiodrama dapat meningkatkan penyesuaian diri siswa kelas X terhadap program peminatan MIPA di SMA Negeri 1 Demak.

\section{SIMPULAN DAN SARAN}

Berdasarkan hasil penelitian ini dapat diambil simpulan bahwa penyesuaian diri siswa kelas $\mathrm{X}$ terhadap program peminatan MIPA sebelum mengikuti bimbingan klasikal teknik sosiodrama masuk dan kategori sedang, setelah mengikuti bimbingan klasikal penyesuaian diri siswa kelas $\mathrm{X}$ terhadap program peminatan MIPA mengalami peningkatan dan masuk dalam kategori tinggi. Dengan demikian, dapat diketahui bahwa bimbingan klasikal teknik sosiodrama dapat digunakan untuk meningkatkan penyesuaian diri siswa kelas $\mathrm{X}$ terhadap program peminatan MIPA.

\section{DAFTAR RUJUKAN}

Astutik, W., Astuti, I., \& Yusuf, A. (2016). Hubungan antara Konsep Diri dengan Penyesuaian Diri Siswa Kelas X SMA Islam Bawari Pontianak. Jurnal Pendidikan dan Pembelajaran, 5(4), 1-12.

Azizah, D. M. (2013). Mengurangi Perilaku Agresif Siswa Melalui Layanan Klasikal Menggunakan Teknik Sosiodrama. Indonesian Journal of Guidance and Counseling: Theory and Application, 2(3), 58-65. 


\section{Jurnal Konseling Indonesia}

http://ejournal.unikama.ac.id/index.php/JKI

ISSN: Print 2476-888X - Online 2476-8901

Vol. 4 No. 1, Oktober 2018. hlm. $36-41$

Creswell, J. W., \& Creswell, J. D. (2017). Research design: Qualitative, Quantitative, and Mixed Methods Approaches. Los Angeles: Sage Publications Inc.

Fazar, M. (2017). Tingkat Kepuasan Siswa dalam Peminatan Program Studi pada Kelas XI IPA SMA Negeri 5 Semarang Tahun Ajaran 2015/2016. Indonesian Journal of Guidance and Counseling: Theory and Application, 6(2), 52-57.

Husna, N. N. m., \& Sutoyo, A. (2016). Pengaruh Layanan Bimbingan Kelompok dengan Teknik Permainan Terhadap Penyesuaian Diri Siswa. Indonesian Journal of Guidance and Counseling: Theory and Application, 5(2), 31-36.

Kusumaningrum, I., Srihartati, M. T., \& Saraswati, S. (2014). Meningkatkan Perilaku Prososial Rendah Melalui Layanan Penguasaan Konten dengan Teknik Sosiodrama. Indonesian Journal of Guidance and Counseling: Theory and Application, 3(3), 1-7.

Makrifah, F. L. (2014). Pengembangan Paket Peminatan dalam Layanan Bimbingan Klasikal untuk Siswa di SMP. Jurnal BK UNESA, 4(3), 1-8.

Marlina, E., Arifin Ahmad, M., \& Pandang, A. (2015). Pengembangan Inventori Peminatan Karir (IPK) sebagai Alat Ukur Arah Pilih Karir Siswa. Jurnal Penelitian Tindakan Bimbingan \& Konseling, $1(1), 59-64$.

Mukhtar, M., Yusuf, S., \& Budiamin, A. (2016). Program Layanan Bimbingan Klasikal untuk Meningkatkan Self-Control Siswa. PSIKOPEDAGOGIA Jurnal Bimbingan dan Konseling, 5(1), 1-16.

Nursafitri, R. (2013). Penerapan Bimbingan Kelompok dengan Teknik Sosiodrama untuk Membantu Meningkatkan Kemampuan Hubungan Interpersonal Siswa. Jurnal BK UNESA, 3(1), 239-244.

Permendikbud. (2014). Peraturan Menteri Pendidikan dan Kebudayaan Tahun 2014 tentang Peminatan pada Pendidikan Menengah. (Nomor 64). Jakarta: Menteri Pendidikan dan Kebudayaan.

Rosidah, A. (2017). Layanan Bimbingan Klasikal untuk Meningkatkan Konsep Diri Siswa Underachiver. Jurnal Fokus Konseling, 3(2), 154-162.

Sudirman, A., Mudjiran, M., \& Rusdinal, R. (2015). Efektivitas Layanan Informasi yang Mengkombinasikan Metode Ceramah, Sosiodrama, dan Diskusi dalam Merubah Persepsi Siswa Tentang Disiplin Belajar. Konselor, 4(1), 33-41.

Supriyo. (2010). Teknik Bimbingan Klasikal. Semarang: Swadaya Publishing.

Sutoyo, A. (2012). Pemahaman Individu-Observasi, Checklist, Interviu, Kuesioner, Sosiometri. Yogyakarta: Pustaka Pelajar.

Winarlin, R., Lasan, B. B., \& Widada, W. (2016). Efektivitas Teknik Sosiodrama Melalui Bimbingan Kelompok untuk Mengurangi Perilaku Agresif Verbal Siswa SMP. Jurnal Kajian Bimbingan dan Konseling, 1(2), 68-73. 